\title{
PENGENALAN KONSEP CODING SEBAGAI TUGAS PROYEK
}

\author{
Ni Made Dwijayani 1), Ni Wayan Cahya Ayu Pratami'1), Ni Nyoman Muryatini'1)
}

1)Sistem Informasi, Fakultas Teknik Informatika, Institut Teknologi dan Bisnis STIKOm Bali, Denpasar, Bali, Indonesia

Corresponding author : Ni Made Dwijayani

E-mail :nimade_dwijayani@stikom-bali.ac.id

Diterima 27 November 2021, Disetujui 30 November 2021

\begin{abstract}
ABSTRAK
Sejak September 2021 pembelajaran tatap muka terbatas (PTM) telah dilaksanakan. PTM terbatas ini memiliki banyak opsi dalam pelaksanaannya, misalnya dengan menggabungkan metode online dan PTM. Perubahan ke pembelajaran online didasarkan pada banyak asumsi, seperti semua anggota masyarakat memiliki akses ke berbagai perangkat. Namun, kenyataan di masyarakat masih banyak yang belum memiliki akses internet secara stabil. Mengatasi masalah tersebut, guru matematika di SMA Negeri 1 Kuta Utara menekankan kepada siswa bahwa pembelajaran matematika tidak hanya untuk mengejar ketercapaian materi yang ada di buku teks, tapi menekankan kepada siswa tentang cara berpikir kritis dan menyelesaiakan masalah. Pengabdian ini memberikan kesempatan kepada guru untuk memiliki pengalaman dalam menyusun sebuah tugas proyek dengan menggunakan konsep coding. Pelaksanaan pengabdian ini terdiri dari tiga tahap yaitu tahap perencanaan, pelaksanaan, dan refleksi. Hasil yang diperoleh yaitu pengabdian ini membantu guru dalam mencari alternatif baru dalam menyusun tugas proyek yang masih mengedepankan tujuan pembelajaran. Selain itu, siswa juga tidak mengalami kesulitan dalam mengerjakan tugas yang diberikan oleh guru.
\end{abstract}

Kata kunci: coding; tugas proyek; matematika.

\begin{abstract}
Since September 2021 limited face-to-face learning (PTM) has been implemented. This limited PTM has many options in its implementation, for example by combining online and PTM methods. The shift to online learning is based on many assumptions, such as all members of society having access to multiple tools. However, the reality is that there are still many people who do not have stable internet access. To overcome this problem, the mathematics teacher at SMA Negeri 1 Kuta Utara emphasized to students that learning mathematics is not only to pursue the achievement of the material in the textbook, but emphasizes to students how to think critically and solve problems. This service provides an opportunity for teachers to have experience in compiling a project assignment using the concept of coding. The implementation of this service consists of three stages, namely the planning, implementation, and reflection stages. The results obtained are that this service helps teachers find new alternatives in compiling project assignments that still prioritize learning objectives. In addition, students also do not have difficulty in doing the assignments given by the teacher.
\end{abstract}

Keywords: coding; project assignment; mathematics.

\section{PENDAHULUAN}

Pandemi COVID-19 telah mengubah rutinitas sehari-hari, dan menjalani normal baru dari jarak sosial, sering membersihkan dan mengenakan masker kain di tempat umum. Lingkungan belajar untuk pandemi COVID-19 sebagian besar online dan jarak jauh. Selain itu sejak September 2021, maka pembelajaran tatap muka terbatas (PTM) telah dilaksanakan. PTM terbatas ini memiliki banyak opsi dalam pelaksanaannya. Beberapa sekolah menerapkan metode shift kepada siswa untuk menghidari kerumunan siswa di kelas dan tetap melaksanakan protokol kesehatan. Adanya kegiatan PTM ini juga membatasi waktu siswa untuk berinteraksi secara langsung kepada guru. Misalnya di SMA Negeri 1 Kuta Utara, siswa bersekolah dari pukul 08.00-11.00. PTM dilaksanakan secara kombinasi dengan metode daring, jadi siswa melaksanakan PTM selama dua minggu dan daring selama dua minggu. Pada jadwal ini siswa hanya bertemu dengan tiga guru mata pelajara dalam waktu 50 menit. Beberapa guru dan siswa mengatakan bahwa waktu yang diberikan sangat sedikit sehingga tidak dapat melaksanakan diskusi secara maksimal.

Perubahan ke pembelajaran online didasarkan pada banyak asumsi, seperti semua anggota masyarakat memiliki akses ke berbagai perangkat (misalnya, komputer desktop, laptop, komputer tablet, dan ponsel), 
konektivitas Internet yang efisien dan tidak terbatas. Bolton (2019) menunjukkan bahwa teknologi, seperti E-learning dan M-Learning, dikombinasikan dengan materi konten matematika saat ini, perlu digunakan di negara berkembang. E-learning mengacu pada pembelajaran yang menggabungkan alat berbasis teknologi untuk bekerja dengan konten pendidikan di luar konteks pendidikan tatap muka tradisional. M-learning juga dikenal sebagai mobile learning, mengacu pada pembelajaran konten pendidikan dengan menggunakan perangkat pribadi, misalnya, ponsel, tablet, laptop dan I-Pad. Ini dapat dianggap sebagai sarana pembelajaran jarak jauh atau online di mana m-learners dapat menggunakan perangkat seluler kapan saja dan di lokasi yang nyaman bagi mereka. Ini merupakan perubahan dari pendekatan pembelajaran tatap muka tradisional. Namun, dalam konteks Afrika Selatan dan konteks banyak negara berkembang lainnya, kenyataannya karena kemiskinan, banyak anggota masyarakat tidak memiliki akses ke Internet, data, dan perangkat (PBB, 2019) untuk berpartisipasi secara setara dalam suatu lingkungan online. Selain itu, banyak masyarakat yang tidak memiliki konektivitas internet yang stabil, terutama mereka yang tinggal di daerah pedesaan (Woolley et al., 2020).

Mengatasi masalah tersebut, guru matematika di SMA Negeri 1 Kuta Utara menekankan kepada siswa bahwa pembelajaran matematika tidak hanya untuk mengejar ketercapaian materi yang ada di buku teks, tapi menekankan kepada siswa tentang cara berpikir kritis dan menyelesaiakan masalah. Mendukung tujuan pembelajaran matematika di SMA Negeri 1 Kuta Utara, maka dilaksanakan pengabdian kepada guru matematika dalam bentuk pengenalan konsep coding tanpa harus menggunakan perangkat elektronik dan jaringan internet untuk mendukung kemampuan matematika siswa karena mempunyai struktur dan keterkaitan yang kuat dan jelas antara konsep-konsep (Wibowo, 2017). Pengenalan coding ini diberikan kepada guru dengan tujuan agar guru memiliki pengalaman dalam menyusun tugas proyek yang berbeda untuk siswa.

\section{METODE}

Pengabdian ini dilaksanakan oleh tiga orang dosen Institut Teknologi dan Bisnis STIKOM Bali serta melibatkan dua belas orang guru matematika di SMA Negeri 1 Kuta Utara. Pelaksanaan pengabdian menggunakan metode Participatory Action Research. Pemilihan metode ini karena Participatory
Action Research merupakan sebuah metode yang menekankan pada praktik, bertujuan ke arah peningkatan, suatu proses siklus, diikuti oleh penemuan yang sistematis, bersifat partisipatif dan mendorong masyarakat (dalam hal in guru) untuk berpartisipasi dalam kegiatan (Bennet, 2020). Dalam pelaksanaannya, pengabdian ini meberikan penyuluhan, pelatihan dan pendampingan selama tiga bulan kepada guru. Kegiatan penyuluhan dan pelatihan dilaksanakan secara tatap muka, sedangkan kegiatan pendampingan dilaksanakan secara daring karena guru sudah melaksanakan kegiatan tatap muka terbatas di sekolah.

Kegiatan ini dilaksanakan melalui tiga tahapan yaitu tahap perencanaan, pelaksanaan, dan refleksi. Pada tahap perencanaan, tim pengabdian melaksanakan wawancara dan pengamatan langsung ke SMA Negeri 1 Kuta Utara. Hal ini dimaksudkan untuk menyelaraskan visi dan misi guru matematika dengan tujuan pengabdian. Hasil dari tahap perencanaan ini adalah kesepakatan antara ketua guru mata pelajaran matematika dengan tim pengabdian untuk melaksanakan pengenalan konsep coding sebagai tugas proyek siswa. Setelah kesepakatan terbentuk, tim pelaksana pengabdian meminta guru matematika untuk memilah topik yang cocok dijadikan tugas proyek dengan menggunakan coding. Hasilnya, terdapat tiga materi dari masing-masing jenjang yaitu materi eksponensial (kelas $\mathrm{X}$ ), materi barisan dan deret (kelas XI), dan materi integral (kelas XII). Setelah menentukan topik, tim pengabdian menyusun materi untuk pelaksanaan penyuluhan.

Tahap yang kedua yaitu tahap pelaksanaan. Pada tahap ini, tim memberikan penyuluhan terkait bagaimana cara menyusun tugas proyek dengan menggunakan kosep coding. Beberapa contoh tugas yang disusun oleh tim, dipresentasikan kepada guru. Setelah melaksanakan penyuluhan, guru mempraktikkan materi yang sudah dipresentasikan. Guru menyusun sendiri tugas yang sesuai dengan jenjang kelas yang diajarnya. Tugas yang disusun oleh guru sudah sesuai dengan tujuan dari pengabdian ini yaitu memuat konsep coding tanpa menggunakan komputer. Seiring juga dengan tujuan pembelajaran matematika yaitu mengembangkan kemampuan siswa dalam hal berpikir kritis dan penyelesaian masalah. Dalam menyusun tugas, guru didampingi oleh tim secara daring. Apabila ada pertanyaan yang memang memerlukan bimbingan secara intensif, tim akan melaksanakan tatap muka melalui aplikasi Zoom untuk mendampingi guru. 
Apabila guru hanya memiliki pertanyaan yang memerlukan jawaban sederhana, maka pendampingan dilaksanakan melalui aplikasi pesan cepat.

Tahap terakhir dari kegiatan ini adalah tahan refleksi. Tujuan dari tahap ini adalah untuk meninjau kembali ketercapaian dari pengabdian. Setelah melaksanakan diskusi dengan guru, maka ditemukan bahwa pengenalan konsep coding ini dapat membantu guru dalam menyusun sebuah tugas proyek yang sesuai dengan tujuan mata pelajaran matematika di SMA Negeri 1 Kuta Utara.

\section{HASIL DAN PEMBAHASAN}

Pengabdian kepada masyarakat di SMA Negri 1 Kuta Utara memiliki tujuan untuk membantu guru matematika dalam menyusun sebuah tugas proyek dengan menggunakan kosep coding. Konsep coding perlu diperkenalkan karena dengan menggunakan coding siswa dapat belajar untuk mengsah logika dan kemampuan pemecahan masalahnya (Floyd, 2021). Pengenalan coding disini adalah dengan memberikan tugas proyek kepada siswa tanpa menggunakan perangkat komputer.

Dalam pelaksanaan pengabdian ini, tim pengabdi memberikan penyuluhan, pelatihan dan pendampingan dalam penyusunan tugas proyek. Materi dari penyuluhan berupa konsep dasar coding yang dapat dikaitkan dengan matematika. Berdasarkan hasil diskusi dengan guru, diperoleh tiga topik yang digunakan dalam penyusunan tugas proyek yaitu eksponensial, barisan dan deret, serta integral. Tim pengabdian memberikan contoh tugas proyek yang dapat dikembangkan oleh guru secara mandiri. Gambar 1 adalah salah satu contoh tugas proyek yang diberikan oleh tim saat penyuluhan.

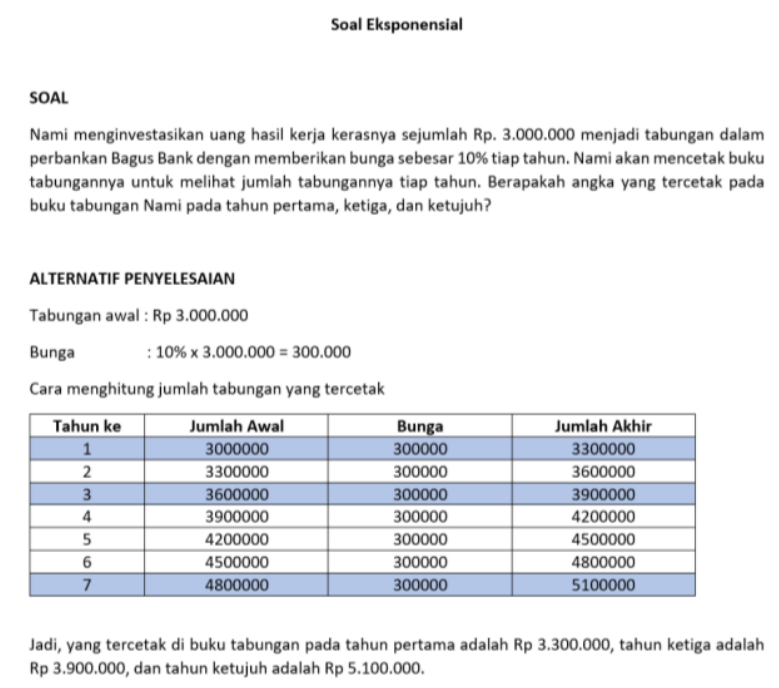

Gambar 1. Tugas proyek dari tim pengabdian
Setelah melaksanakan penyuluhan, tim dan guru melaksanakan kegiatan pelatihan. Guru diminta untuk mengerjakan sebuah tugas proyek yang sesuai dengan topik yang dipilih oleh masing-masing guru. Dalam kegiatan pelatihan ini ditemukan bahwa masih ada guru yang mengalami kebingungan saat menyusun tugas yang terkait dengan konsep coding. Guru masih berpatokan bahwa tugas yang disusun harus ada menggunakan rumus tertentu yang sama seperti di buku teks. Setelah diberikan pendampingan oleh tim, maka guru tersebut dapat mengubah konteks soalnya sehingga tidak menitikberatkan kepada menghitung volume dengan integral tetapi menyelidiki bentuk yang terjadi jika sebuah benda diputar. Pada Gamber 2 berikut adalah contoh tugas yang disusun oleh guru sebelum dan setelah mendapatkan pendampingan.

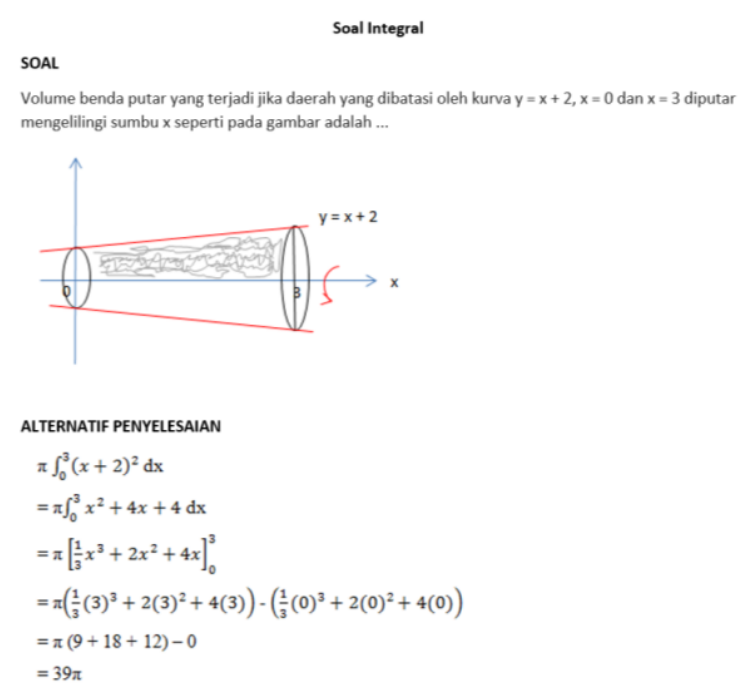

Gambar 2. Tugas proyek oleh guru (sebelum pendampingan)

Setelah mendapatkan pendampingan dari tim, maka guru sudah mulai paham bahwa konsep coding yang dimaksud disini adalah menuntun siswa untuk berpikir logis dan dapat memecahkan masalah, tidak hanya sekedar menghitung dengan menggunakan rumus yang sudah ada. Berikut adalah tugas proyek oleh guru setelah mendapatkan pendampingan. 


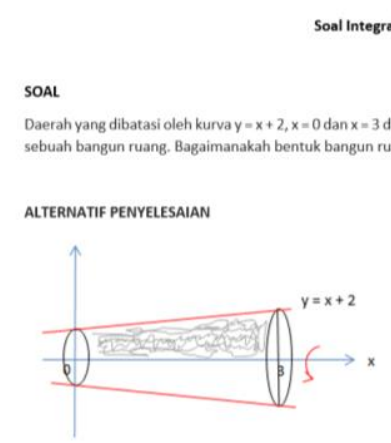

Gambar 3. Tugas proyek oleh guru (setelah pendampingan)

Gambar 4 adalah salah satu contoh tugas dari guru pada topik barisan dan deret.

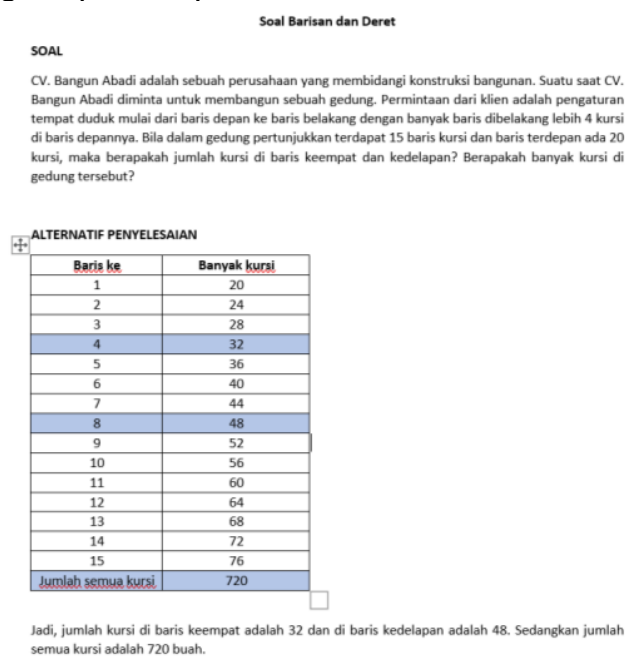

Gambar 4. Tugas proyek oleh guru

Setelah melaksanakan pelatihan, guru diminta untuk menyusun sebuah tugas proyek secara mandiri. Pada tahap ini, tim bertugas untuk mendampingi guru secara daring. Dalam kegiatan pendampingan, tidak ada masalah berarti yang dihadapi oleh guru.

Pelaksanaan pengabdian selama tiga bulan ini menghasilkan lima belas tugas proyek yang disusun secara kelompok dan individu oleh guru matematika SMA Negeri 1 Kuta Utara. Tugas proyek ini dapat digunakan oleh guru sebagai salah satu tugas kepada siswa selama kegiatan PTM karena pembelajaran daring memiliki keterbatasan-keterbatasan tersendiri dimana pendidik tidak bisa memantau secara langsung para peserta didik pada saat kegiatan belajar berlangsung, serta sulitnya para peserta didik untuk memahami bahan ajar yang disampaikan secara online (Firman \& Rahayu, 2020). Tugas proyek yang disusun guru terlihat sangat mudah dan membuat siswa tidak terbebani dalam mengerjakan tugas. Hal tersebut diperoleh dari hasil kuesioner kepada guru yang menyatakan bahwa topik pengabdian ini sangat membantu guru dalam mencari alternatif tugas untuk siswa. Selain itu, guru juga menyatakan bahwa tuags yang diberikan sangat mudah dalam proses penyusunannya. Respons dari siswa juga menyatakan bahwa tugas yang diberikan tidak terlalu sulit untuk dikerjakan karena tidak memerlukan sebuah rumus, tapi bisa menggunakan logika siswa secara umum.

\section{SIMPULAN DAN SARAN}

Pelaksanaan pengabdian ini memberikan hasil bahwa tugas proyek dengan menggunakan konsep coding dapat diterima dengan baik oleh guru dan siswa. Guru tidak mengalami kesulitan dalam menyusun tugas dan siswa tidak merasa terbebani saat mengerjakan tugas tersebut.

Kedepannya diharapkan pengabdian serupa dapat dilaksanakan dengan jangka waktu yang lebih lama dan meliputi lebih banyak topik serta mata pelajaran.

\section{UCAPAN TERIMAKASIH}

Terima kasih penulis ucapkan kepada tim pengabdian yang selalu mendukung semua kegiatan, Kepala SMA Negeri 1 Kuta Utara yang memberikan izin untuk melaksanakan pengabdian, dan guru matematika SMA Negeri 1 Kuta Utara yang sangat aktif dan kooperatif selama kegiatan pengabdian ini berlangsung.

\section{DAFTAR RUJUKAN}

Bennett, M. (2020). A Review of the Literature on the Benefits and Drawbacks of Participatory Action Research. First Peoples Child \& Family Review, 1(1). https://doi.org/10.7202/1069582ar

Bolton, L. (2019). Foundational mathematics education in developing countries. Institute of Development Studies Retrieved from. https://resourcecentre.savethechildren. net/node/16285/pdf/657_foundational_ mathematics_education_in_developing countries.pdf

Firman, \& Rahayu, S. (2020). Pembelajaran Online Di Tengah Pandemi Covid-19. Indonesian Journal of Educational Science (IJES) 2(2):81-89.

Floyd, S. (2021). Problem Solving \& Coding. Retrieved

from https://researchideas.ca/ /mc/problemsolving-coding/.

United Nations. (2019). Digital Economy Report 2019. Value creation and capture: Implications for developing countries. https://unctad.org/system/files/officialdocument/der2019_en.pdf

Wibowo, A. (2017). Pengaruh pendekatan pembelajaran matematika realistik dan saintifik terhadap prestasi belajar, 
kemampuan penalaran matematis dan minat belajar. Jurnal Riset Pendidikan Matematika, $\quad 4(1)$, 1. https://doi.org/10.21831/jrpm.v4i1.100 66

Woolley, S., Sattiraju, N., \& Moritz, S. (2020). U.S. Schools trying to teach online highlight a digital divide. Bloomberg Businessweek, 1-6. Retrieved from https://www.bloomberg.com/news/artic les/2020-03-26/covid-19-schoolclosures-reveal-disparity-in-access-tointernet 